I

\title{
Gasbuggy Site Assessment and Risk Evaluation
}

March 2011, Rev. 1

Approved for public release; further dissemination unlimited

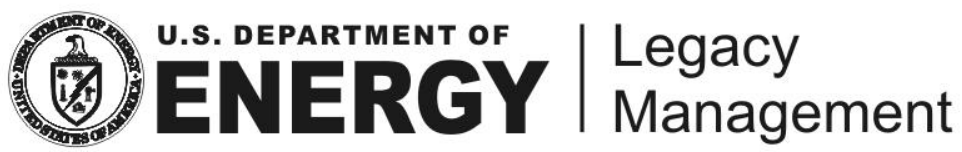


Available for sale to the public from:

U.S. Department of Commerce

National Technical Information Service

5301 Shawnee Road

Alexandria, VA 22312

Telephone: 800.553.6847

Fax: 703.605.6900

E-mail: orders@ntis.gov

Online Ordering: http://www.ntis.gov/help/ordermethods.aspx

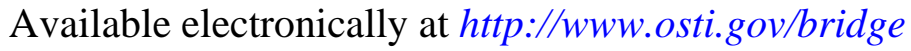

Available for a processing fee to U.S. Department of Energy and its contractors, in paper, from:

U.S. Department of Energy

Office of Scientific and Technical Information

P.O. Box 62

Oak Ridge, TN 37831-0062

Phone: 865.576 .8401

Fax: 865.576.5728

Email: reports@adonis.osti.gov

Reference herein to any specific commercial product, process, or service by trade name, trademark, manufacturer, or otherwise, does not necessarily constitute or imply its endorsement, recommendation, or favoring by the United States Government or any agency thereof or its contractors or subcontractors. 


\title{
Gasbuggy Site Assessment and Risk Evaluation
}

\author{
March 2011, Rev. 1
}

Approved for public release; further dissemination unlimited 
This page intentionally left blank 


\section{Contents}

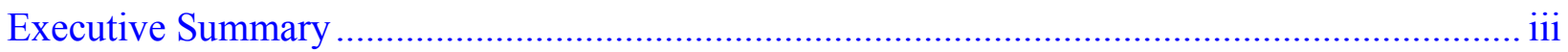

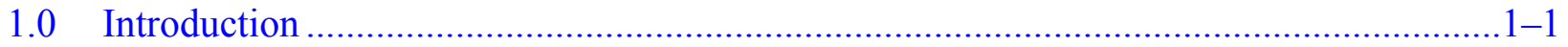

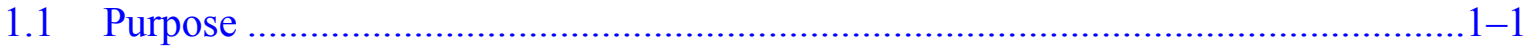

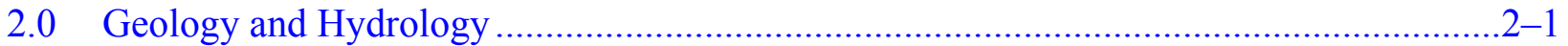

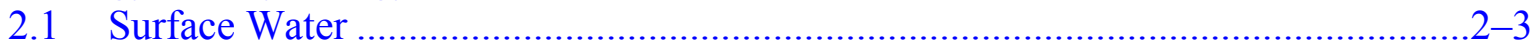

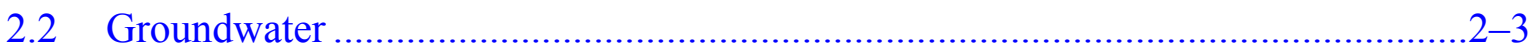

3.0 Description of the Gasbuggy Test and Its Effects ...........................................................

4.0 Conceptual Model ..................................................................................................

4.1 Contamination Potential for the Ojo Alamo Sandstone Formation...........................4-1

4.2 Contamination Potential for Natural Gas Produced from the Pictured Cliffs Sandstone Formation .......................................................................................

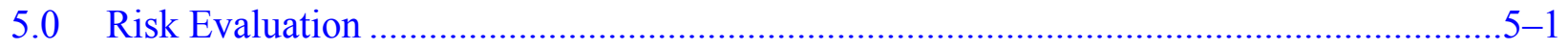

5.1 Tritium as Indicator Radionuclide ...................................................................5-1

5.2 Natural Gas Production and Processing ……………..............................................5-2

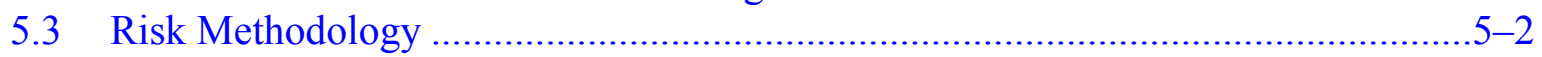

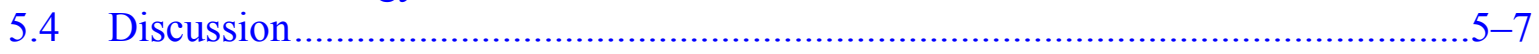

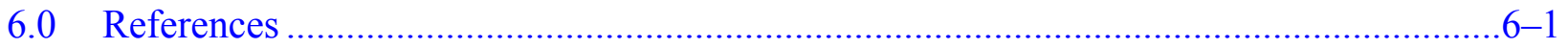

\section{Figures}

Figure 1-1. Location Map for the Gasbuggy Site................................................................ 1-2

Figure 2-1. Generalized Geologic Cross Section of the San Juan Basin, New Mexico.............. 2-2

Figure 2-2. Gasbuggy Site Cross Section.................................................................................. 2-3

Figure 3-1. Gasbuggy Test Well Locations ………............................................................ 3-2

Figure 5-1. Tritium Decay Curve ........................................................................................... 5-1

Figure 5-2. Typical Well Drilling Arrangement ................................................................. 5-4

Figure 5-3. Typical Well Head Area with Separator and Separated Liquid Storage Tank........ 5-5

\section{Tables}

Table 5-1. Calculated Air Concentrations of Tritium (pCi/L) ............................................... 5-6

Table 5-2. Concentrations of Tritium in Produced Water (pCi/L) for Selected Air Concentrations and Humidities (Temperature at $50{ }^{\circ} \mathrm{C}$ ) ......................................... 5-7

\section{Appendix}

Appendix A Air Risks 
This page intentionally left blank 


\section{Executive Summary}

This report describes the geologic and hydrologic conditions and evaluates potential health risks to workers in the natural gas industry in the vicinity of the Gasbuggy, New Mexico, site, where the U.S. Atomic Energy Commission detonated an underground nuclear device in 1967. The 29-kiloton detonation took place 4,240 feet below ground surface and was designed to evaluate the use of a nuclear detonation to enhance natural gas production from the Pictured Cliffs Formation in the San Juan Basin, Rio Arriba County, New Mexico, on land administered by Carson National Forest.

A site-specific conceptual model was developed based on current understanding of the hydrologic and geologic environment. This conceptual model was used for establishing plausible contaminant exposure scenarios, which were then evaluated for human health risk potential.

The most mobile and, therefore, the most probable contaminant that could result in human exposure is tritium. Natural gas production wells were identified as having the greatest potential for bringing detonation-derived contaminants (tritium) to the ground surface in the form of tritiated produced water. Three exposure scenarios addressing potential contamination from gas wells were considered in the risk evaluation: a gas well worker during gas-well-drilling operations, a gas well worker performing routine maintenance, and a residential exposure. The residential exposure scenario was evaluated only for comparison; permanent residences on national forest lands at the Gasbuggy site are prohibited.

The results of this risk evaluation will be used to guide the U.S. Department of Energy's (DOE's) future surveillance and monitoring activities in the area to ensure they are adequately protective of the most likely future land use that could result in exposure to test-related contamination. The evaluation is not intended to be a comprehensive risk assessment for the site but is intended to provide assurance that DOE's monitoring approach can detect the presence of site-related contamination at levels well below those that would pose a risk to human health.

Tritium must be inside the body to present an exposure risk. Because the water produced by a natural gas well is never used for drinking, only inhalation was considered as a feasible pathway. The risk evaluation determined concentrations of tritium in air that would result in radiation doses exceeding limits for acceptable incremental lifetime cancer risk. These concentrations were calculated based on evaporation of tritiated produced water under various relative humidity and evaporation rate scenarios.

The worst-case exposure scenario for a gas worker required a tritium concentration in produced water of 227,000 picocuries per liter to result in an unacceptable incremental lifetime cancer risk. Given that gas well monitoring to date has not detected tritium, and that the existing tritium continues to decay off, it is extremely unlikely that tritium concentrations in produced water would ever approach levels high enough to present an unacceptable risk to human health.

These risk evaluation results will assist DOE with decision making regarding future surveillance and maintenance activities. 
This page intentionally left blank 


\subsection{Introduction}

The Gasbuggy site is in northern New Mexico in the San Juan Basin, Rio Arriba County (Figure 1-1). The Gasbuggy experiment was designed to evaluate the use of a nuclear detonation to enhance natural gas production from the Pictured Cliffs Formation, a tight, gas-bearing sandstone formation. The 29-kiloton-yield nuclear device was placed in a 17.5 -inch wellbore at 4,240 feet (ft) below ground surface (bgs), approximately $40 \mathrm{ft}$ below the Pictured Cliffs/Lewis shale contact, in an attempt to force the cavity/chimney formed by the detonation up into the Pictured Cliffs Sandstone. The test was conducted below the southwest quarter of Section 36, Township 29 North, Range 4 West, New Mexico Principal Meridian.

The device was detonated on December 10, 1967, creating a 335-ft-high chimney above the detonation point and a cavity $160 \mathrm{ft}$ in diameter. The gas produced from GB-ER (the emplacement and reentry well) during the post-detonation production tests was radioactive and diluted, primarily by carbon dioxide. After 2 years, the energy content of the gas had recovered to 80 percent of the value of gas in conventionally developed wells in the area.

There is currently no technology capable of remediating deep underground nuclear detonation cavities and chimneys. Consequently, the U.S. Department of Energy (DOE) must continue to manage the Gasbuggy site to ensure that no inadvertent intrusion into the residual contamination occurs. DOE has complete control over the $1 / 4$ section (160 acres) containing the shot cavity, and no drilling is permitted on that property. However, oil and gas leases are on the surrounding land. Therefore, the most likely route of intrusion and potential exposure would be through contaminated natural gas or contaminated water migrating into a producing natural gas well outside the immediate vicinity of ground zero.

\subsection{Purpose}

The purpose of this report is to describe the current site conditions and evaluate the potential health risks posed by the most plausible contaminant exposure scenario, drilling of natural gas wells near the site. The results of this risk evaluation will guide DOE's future surveillance and monitoring activities in the area to ensure that site conditions are adequately protective of human health. This evaluation is not a comprehensive risk assessment for the site; it is intended to provide assurance that DOE's monitoring approach can detect the presence of site-related contamination at levels well below those that would pose an unacceptable risk to human health. 


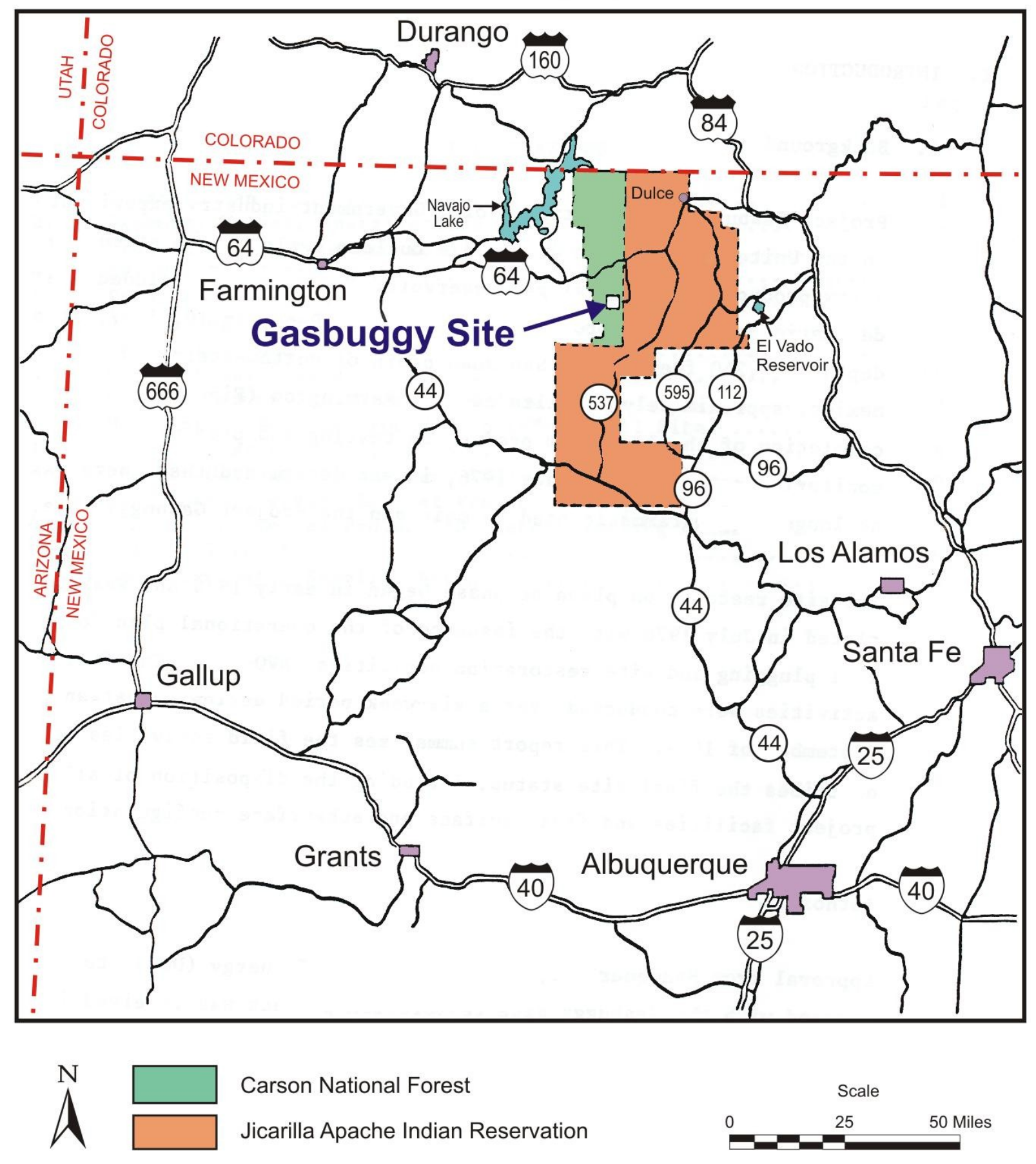

Figure 1-1. Location Map for the Gasbuggy Site 


\subsection{Geology and Hydrology}

The Gasbuggy site lies within the San Juan Structural Basin, a northwest-trending depression along the eastern edge of the Colorado Plateau. The basin is bounded on the north by the San Juan Mountains, on the east by the Sierra Nacimiento Mountains, on the west by the Chuska Mountains, and on the south by the Zuni Mountains. At the center of the trough-like basin, the sedimentary rocks range up to $14,000 \mathrm{ft}$ in thickness. The beds dip from the margin of the basin toward the deepest portion of the basin. Outcrops of Jurassic and Cretaceous rocks rim the basin and are prevalent to the south and west. Faulting occurs in portions of the basin, with displacements up to thousands of feet (New Mexico 2003). Stone et al. (1983) describe the depositional sequence of the basin.

The mineral-rich environment of the San Juan Basin was the primary factor in its selection as a site for the Gasbuggy test. Oil, gas, uranium, and coal have all been extracted from the basin. In areas where the energy resources are present, groundwater is saline. Figure $2-1$ is a generalized geologic cross section of the San Juan Basin. The Tertiary Rocks Undivided shown in Figure 2-1 comprise several formations, including the San Jose and Nacimiento Formations. Figure 2-2 is a cross section across the Gasbuggy site.

Recent alluvium is restricted to valleys along the major stream and tributary channels. The San Jose Formation crops out throughout much of the central basin and is present near the Gasbuggy site. The formation is a coarse, arkosic sandstone interbedded with mudstone. Its thickness ranges from $200 \mathrm{ft}$ in the southwestern portion of the basin to 2,700 ft near Gobernador west of the Gasbuggy site. The State of New Mexico considers the San Jose Formation an aquifer (New Mexico 2003).

The Nacimiento (Animas equivalent) Formation underlies the San Jose; both formations are typical continental floodplain deposits. The Nacimiento is interbedded black mudstone and white, coarse sandstone at the base, and the upper portion is dominated by sandstone and mudstone beds. The sandstone units are prevalent in forming the distinct slopes of this formation. At the Gasbuggy site, the formation is represented by a 3,500-ft sequence of fine- to mediumgrained, locally conglomeratic sandstone interbedded with claystone and sandy shale. The State of New Mexico considers the Nacimiento Formation an aquifer (New Mexico 2003).

The Ojo Alamo Sandstone is composed of conglomeratic sandstones, sandstones, and shale common in basin sedimentary deposits. The conglomerate pebbles lie in thin, discontinuous stringers and in poorly sorted beds up to $10 \mathrm{ft}$ thick in the northwestern portion of the area. At the Gasbuggy site, the formation is light-gray, medium- to fine-grained sandstone with minor shale interbeds and is $180 \mathrm{ft}$ thick. The State of New Mexico considers the Ojo Alamo an aquifer (New Mexico 2003).

The Kirtland Shale overlies the Fruitland Formation and has been a significant petroleum play in the basin. Although the Kirtland Shale was originally described by Brown (1910) as part of the Ojo Alamo Sandstone, it is commonly lumped with the Fruitland Formation because of its similar hydrologic properties. The boundaries of these two formations are not clearly defined, and the descriptions are incomplete; however, investigators agree that the carbonaceous shale and the coal are within the Fruitland Formation. Both formations consist of fine-grained sands, sandy shale, shale, and clayey sandstone sequences. At the Gasbuggy site, these formations together are $260 \mathrm{ft}$ thick and consist of gray to dark-green shale and siltstone interbedded with thin, very fine grained sandstone. 


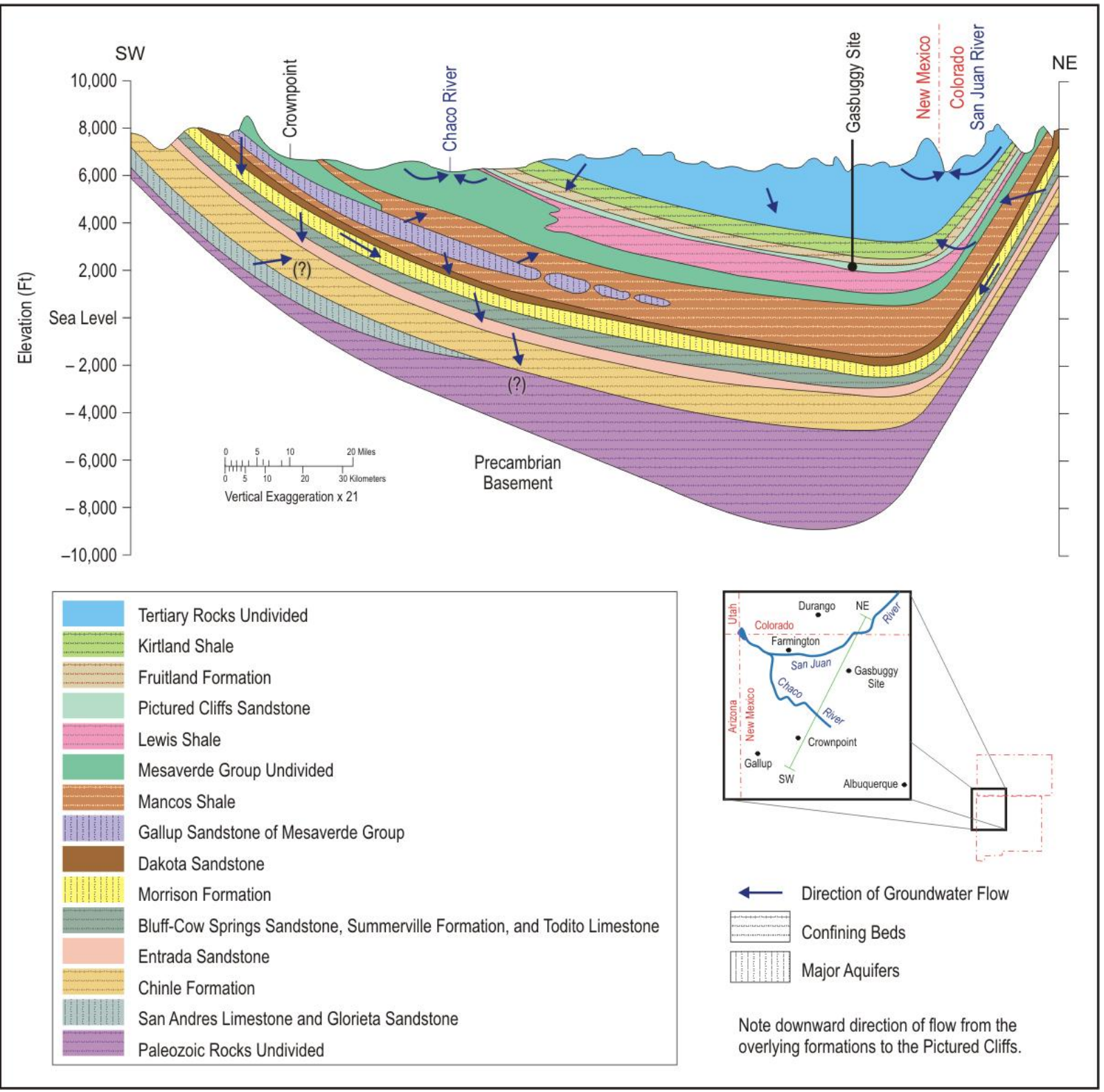

Figure 2-1. Generalized Geologic Cross Section of the San Juan Basin, New Mexico

The Pictured Cliffs Sandstone is the latest marine sandstone represented in the basin. The unit was named for the pictographs on the cliff-forming arkosic outcrops. Thickness ranges from 25 to $290 \mathrm{ft}$ across the basin. Interbedded sandstone and mudstone mark the contact between the Pictured Cliffs and the Lewis Shale. The formation at the site is a light-gray, very fine grained to fine-grained sandstone interbedded with dark sandy shale $290 \mathrm{ft}$ thick. Gas production from the Pictured Cliffs is characterized by flow along natural joints, fractures, and bedding planes. Flow in the rock matrix is much slower than in the joints and fractures due to the low permeability of the rock matrix.

The Pictured Cliffs intertongues with the underlying Lewis Shale. The Lewis Shale is a gray to black shale interbedded with sandy limestone, sandstone, and bentonite. 


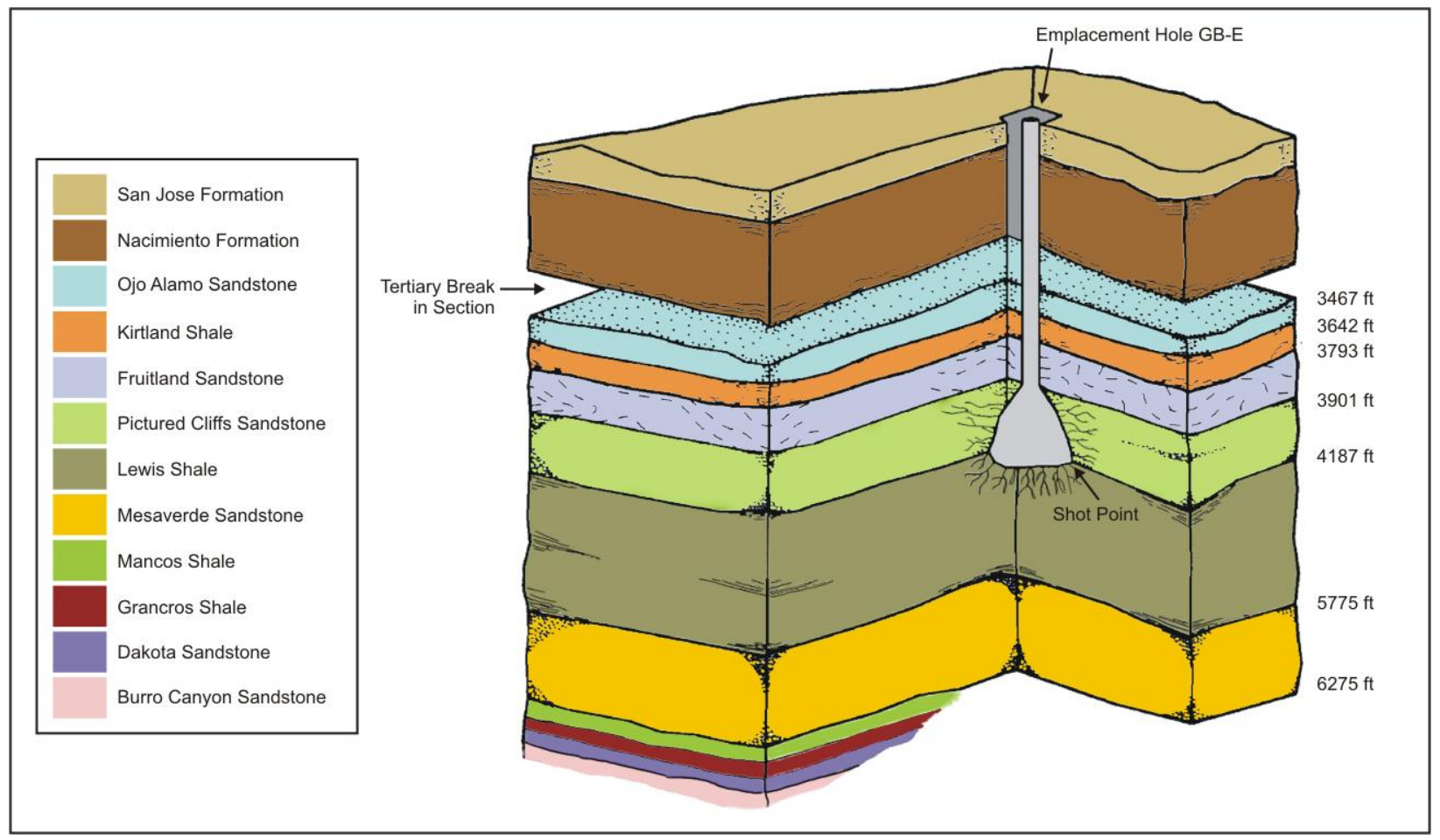

Figure 2-2. Gasbuggy Site Cross Section

\subsection{Surface Water}

The Continental Divide crosses the San Juan Basin and separates the Rio Grande and Colorado River drainages. The San Juan River flows into New Mexico from Colorado and exits New Mexico into Utah. Surface water near the Gasbuggy site flows toward the San Juan River. Spring water is from the San Jose Formation, which crops out across the area.

\subsection{Groundwater}

The San Juan Basin structure and geology control groundwater conditions within the basin. The San Juan Hydrologic Unit Regional Water Plan prepared by the State of New Mexico has a comprehensive discussion of the area's groundwater resources (New Mexico 2003).

The New Mexico groundwater protection regulations specify that all groundwater in the state that has an existing total dissolved solids concentration less than 10,000 milligrams per liter must be protected for present or potential future use as domestic and agricultural water supply (Benjamin and Belluck 1994). For reference, the U.S. Environmental Protection Agency (EPA) secondary drinking water standard for total dissolved solids is 500 milligrams per liter. The San Jose, Nacimiento, and Ojo Alamo Formations (Figure 2-2) are aquifers containing groundwater that the State considers "acceptable and retrievable" (New Mexico 2003).

The Fruitland and Kirtland Formations were unsaturated at Gasbuggy GB-1 when this well was drilled, and the Pictured Cliffs Formation yielded a very small amount of water. The San Juan Hydrologic Unit Regional Water Plan does not discuss the Pictured Cliffs Sandstone as an aquifer. 
Groundwater flow from the Gasbuggy site is believed to be to the west-northwest to discharge points along the San Juan River (Mercer 1970). At the site, hydraulic head values decrease with depth, indicating a potential for downward flow (Sokol 1970).

Water supply wells in the general area tap both the alluvium and the underlying Tertiary sandstones at depths between 54 and $229 \mathrm{ft}$ (Mercer 1968). 


\subsection{Description of the Gasbuggy Test and Its Effects}

The 29-kiloton Gasbuggy detonation created a cavity of approximately $80 \mathrm{ft}$ in radius with a chimney of approximately $335 \mathrm{ft}$ in height. The chimney was created by collapse and bulking of overlying Pictured Cliffs Formation material into the cavity after the gases cooled and condensed (Holzer 1970). Observations of cable and casing breaks in wells GB-1 and GB-ER (Figure 3-1) indicated distances for fracturing of $480 \mathrm{ft}$ and $444 \mathrm{ft}$, respectively. A strong influence of geologic weaknesses and discontinuities on fracture extent was evident; the lower portion of the Pictured Cliffs was more extensively fractured than the upper part, which was apparently protected by an intervening coal and shale layer (Holzer 1970).

A compressional shock wave created by an underground nuclear explosion travels to land surface, causing a temporary rise in surface elevation. Surface spall can occur where the surface layers split away under the influence of tensile reflections from the surface and subsequent slapdown when the layers fall. This can result in fracturing of the near-surface rock, confined to the upper tens to several hundreds of feet below land surface and unconnected to fractures from the cavity.

Permeability enhancement as a result of the nuclear test was below expectations. Testing revealed lower-than-expected production performance, which was attributed to the following factors: (1) overestimation of formation permeability prior to the test; (2) closing of newly created, unsupported fractures; and (3) sealing of the cavity walls by solidified melt glass (Stosur 1977). Although permeability in the region within one cavity radius of the chimney may have increased by a factor of up to 100 over the pretest permeabilities, the fracture zone is relatively small compared to the surrounding contributing reservoir, and production is ultimately limited by that unaffected zone.

Although the stemming plan was designed to seal the emplacement well and prevent any leakage from the test, a small amount of radioactivity was detected at ground surface about 8 hours after the detonation. The leakage apparently occurred in the explosive arming and firing cable, where breaks in that cable possibly allowed radioactive gas to leak to porous portions of the stemmed emplacement hole (LRL 1968a). After 1.5 hours, all cables were cut and sealed at the wellhead (LRL 1968b). Analysis of a sample of the gas leaking up the cables determined that the only radioactive materials present were isotopes of the noble gases krypton and xenon (AEC 1971). Wet stemming material encountered on reentry indicated that water migrated upward under hydrostatic pressure from the Ojo Alamo (at 3,550 ft bgs) to at least 3,260 $\mathrm{ft}$ bgs and possibly up as far as 3,029 $\mathrm{ft}$ bgs. This water leak was attributed to poor cement bonding in the stemming or explosion-caused grout failure, or possibly both (LRL 1968a). Downward water migration into the chimney and cavity also occurred. Investigations into the unexpected amount of water encountered during gas production testing determined that the chemistry matched that of the Ojo Alamo groundwater (Power and Bowman 1970). Hydraulic analysis and well history indicated leaks along the emplacement casing to be the pathway.

As in all underground nuclear tests, the majority of the radioactivity is contained in the melt glass in the bottom of the cavity. Krypton- 85 and tritium account for essentially all of the radioactivity in the natural gas produced from the Gasbuggy chimney. The detonation deposited about $350 \pm 20$ curies of krypton- 85 and about $3.6 \times 10^{4}$ curies of tritium in the chimney (Smith and Momyer 1968). The short-lived isotopes of xenon-133 and argon-37 were also 


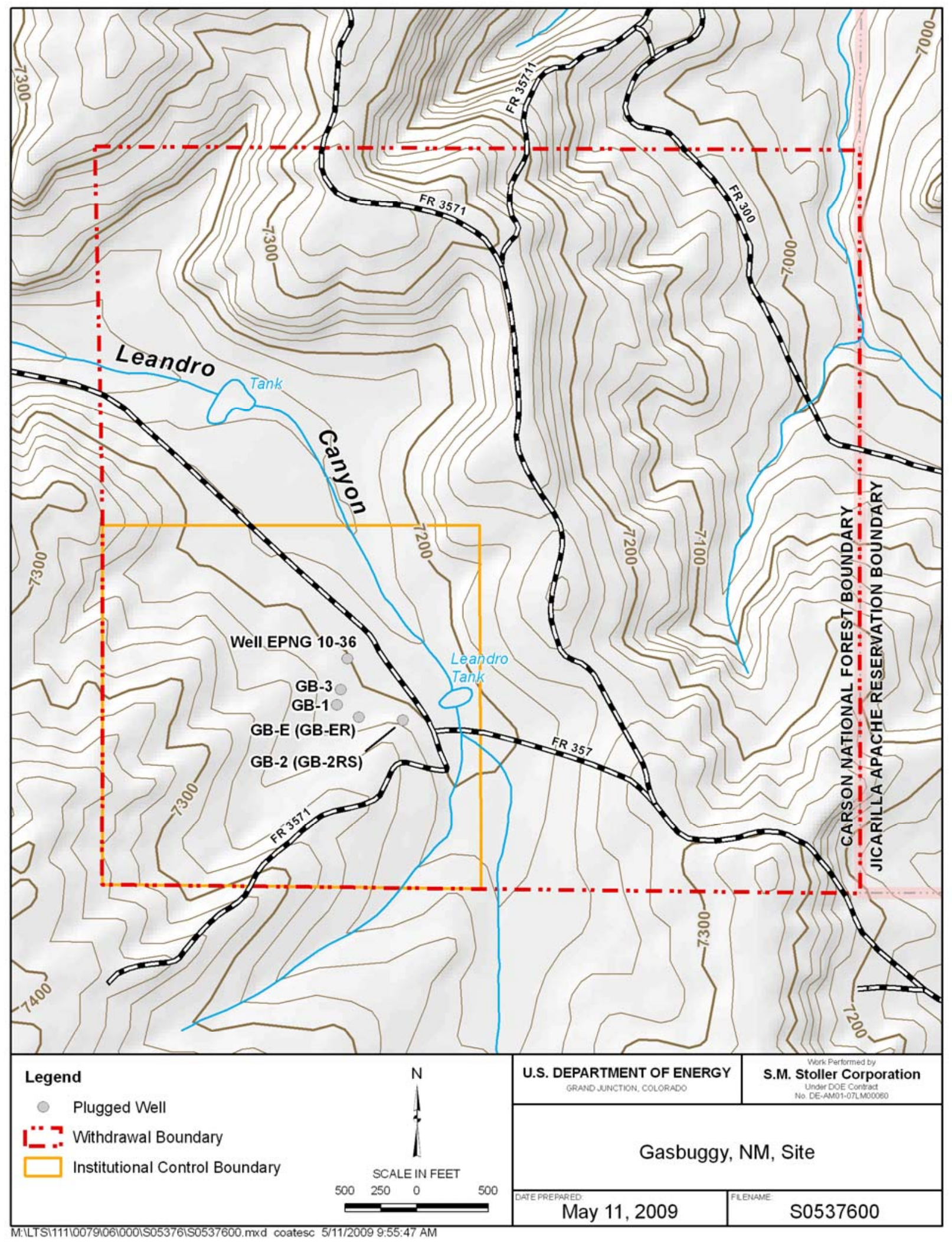

Figure 3-1. Gasbuggy Test Well Locations 
detected in gas samples from the chimney but have since decayed away. In addition, minor amounts of argon-39 and carbon-14 were detected in the chimney gas. Significant quantities of radionuclides were removed from the chimney by gas-flow testing. The tritium was found in the form of tritiated methane, some higher hydrocarbon fractions, tritiated hydrogen, as well as tritiated water. Only 5 percent of the total estimated tritium was found in the gas phase (Holzer 1970). 
This page intentionally left blank 


\subsection{Conceptual Model}

The Gasbuggy site conceptual model identifies two potential pathways for exposure to detonation-derived contamination. One pathway is exposure to contaminated groundwater in the Ojo Alamo Formation; the second pathway is exposure to contaminated natural gas produced from the Pictured Cliffs Formation. Contamination of the Ojo Alamo by detonationderived constituents is considered highly unlikely. Contamination of produced natural gas by detonation-derived constituents is considered feasible. Tritium is the most mobile of the contaminants that remain in significant quantities at the Gasbuggy site; therefore, the discussions in Sections 4 and 5 focus on tritium as the primary contaminant of concern.

\subsection{Contamination Potential for the Ojo Alamo Sandstone Formation}

The State of New Mexico has identified the Ojo Alamo Sandstone Formation as an aquifer containing groundwater that is acceptable and retrievable (New Mexico 2003). Two pathways for contaminants to enter the Ojo Alamo Formation have been identified. One is through failed well casings in wells completed within the directly impacted formations near the detonation cavity. The only wells in the immediate vicinity were the wells installed by the U.S. Atomic Energy Commission as part of the Gasbuggy experiment and well EPNG 10-36. All these wells have been plugged and abandoned, thereby eliminating this potential pathway.

The second pathway for contaminants to potentially enter the Ojo Alamo Formation would be through fractures created by the detonation that extend from the detonation cavity into the Ojo Alamo. Fracturing from the Gasbuggy test was predicted to extend out to a radius of $425 \mathrm{ft}$. Post-test observations in wells GB-1 and GB-ER showed fractures extending to $480 \mathrm{ft}$ and $444 \mathrm{ft}$, respectively, consistent with the pre-test prediction (DOE 2002). Also, a chimney height of $335 \mathrm{ft}$ above the detonation point was observed. Since the lower boundary of the Ojo Alamo Sandstone is approximately $600 \mathrm{ft}$ above the detonation point, the fractures likely do not extend into the Ojo Alamo, thereby rendering this potential pathway highly unlikely.

Investigations into the tritium contamination that was detected in EPNG 10-36 (DRI 2003) prior to plugging of that well revealed that the detected tritium did not originate in the Ojo Alamo, which is further evidence that the Ojo Alamo has not been contaminated by detonation-derived constituents.

Finally, the hydraulic head in the Ojo Alamo Formation is significantly greater than the hydraulic head in the Pictured Cliffs Formation, which means that groundwater flow would be downward toward the Pictured Cliffs from the Ojo Alamo, not vice versa.

As a result of these considerations, the Ojo Alamo is not considered a medium for contaminant transport of the Gasbuggy detonation-derived contaminants. 


\subsection{Contamination Potential for Natural Gas Produced from the Pictured Cliffs Sandstone Formation}

The potential migration pathway is transport of radionuclide-contaminated natural gas resulting from the development of the surrounding natural gas resources. Pores in the Pictured Cliffs Formation are filled with both gas and water. Tritium produced by the Gasbuggy test exists as both liquid water and water vapor and is capable of being exchanged between phases. In addition to pressure-driven flow, radionuclides are transported in both phases by diffusion in the porous medium and fractures. The fracture permeability is higher than the permeability of the porous medium, such that the most rapid transport mechanism is flow of tritiated gas through fractures (DOE 2002). In a natural gas production scenario, production from the reservoir is likely controlled by the spatial extent and connectivity of fractures that intercept the wellbore.

The Pictured Cliffs is an unconventional, continuous-type play defined by gas production from stratigraphic traps in sandstone reservoirs enclosed in shale or coal. The stratigraphy surrounding the Gasbuggy test is reasonably predictable because the Pictured Cliffs is a 300-ft-thick, laterally continuous sandstone formation in the area. The Lewis Shale underlying the Pictured Cliffs, and the sandstone, shale, and siltstone of the Fruitland Formation overlying the Pictured Cliffs, are believed to behave as low-permeability confining layers for the natural gas. Marine shale in the Lewis Shale and nonmarine shale of the Fruitland Formation are also interpreted as the source of the gas (DRI 2009).

Compared to the Pictured Cliffs, higher permeability and porosity are expected in the nuclear chimney above the test cavity, in the fracture zone surrounding the nuclear explosion, and in the zone hydraulically fractured around any future production wells. Observations after the nuclear test indicate that the geometry of the strata, preexisting weaknesses such as joints, and presence of low-density coals influenced the nuclear fractures more strongly than initially predicted. The intensity of fracturing due to the nuclear test varies with distance: broken and sagged beds of rock occur in the chimney; intact rock but with broken matrix or cementing material occurs at an intermediate distance; and farther outward the fracturing is present only in the sense of movement along preexisting rock weaknesses (DRI 2009).

Because the transport velocity is much faster in the gas phase than in the liquid phase under the observed water saturation and permeability conditions, radionuclides with a gas phase (principally tritium, but also possibly small amounts of krypton-85 and carbon-14) are contaminants of potential interest. Only a small fraction of the initial post-test gas was estimated to remain in the chimney after the gas-flow tests. However, over 90 percent of the tritium was present in the liquid phase rather than gas, and the bulk of that remained in the subsurface. Tritiated liquid water can readily exchange into the water vapor phase. Thus, tritium is the contaminant of greatest interest (DRI 2009).

Subsequent to the testing, migration has occurred as a result of diffusion. Gas-phase diffusion is orders of magnitude more important than liquid-phase diffusion due to the difference in diffusion coefficients. Nonetheless, exchange between phases will equilibrate tritium concentrations between gas and liquid, such that the tritium concentration in both phases can be affected within the zone of diffusion. Transport by diffusion, even in the gas phase, is limited in distance, particularly given the ongoing process of radioactive decay. 


\subsection{Risk Evaluation}

This evaluation provides an estimate of contaminant levels that would be of concern for the most reasonable exposure scenario - drilling of natural gas wells near the test area. DOE owns all surface and subsurface rights for the $1 / 4$ section containing the test cavity, and no drilling is permitted within this property. Therefore this evaluation focuses on potential drilling activities that could take place outside the $1 / 4$ section boundary. The approach used in this evaluation is similar to that conducted by Argonne National Laboratory for the Project Rulison site (DOE 2008).

\subsection{Tritium as Indicator Radionuclide}

The test cavity is assumed to be the source of radionuclides generated during the underground test. Although many of the radionuclides are trapped in the vitrified melt rock that formed through recondensation of the vaporized rock surrounding the test, gas-phase radionuclides are of concern with respect to migration, due to their mobility. Tritium is generally of greatest concern because it is the most abundant radionuclide that occurs in the gas phase. Tritium decays to a stable isotope of helium, which, at the earth's surface, is lost to the atmosphere and is not a human health concern. Approximately $99.9 \%$ of the tritium will have decayed off in 110 years from the Gasbuggy test date of 1967 (Figure 5-1).

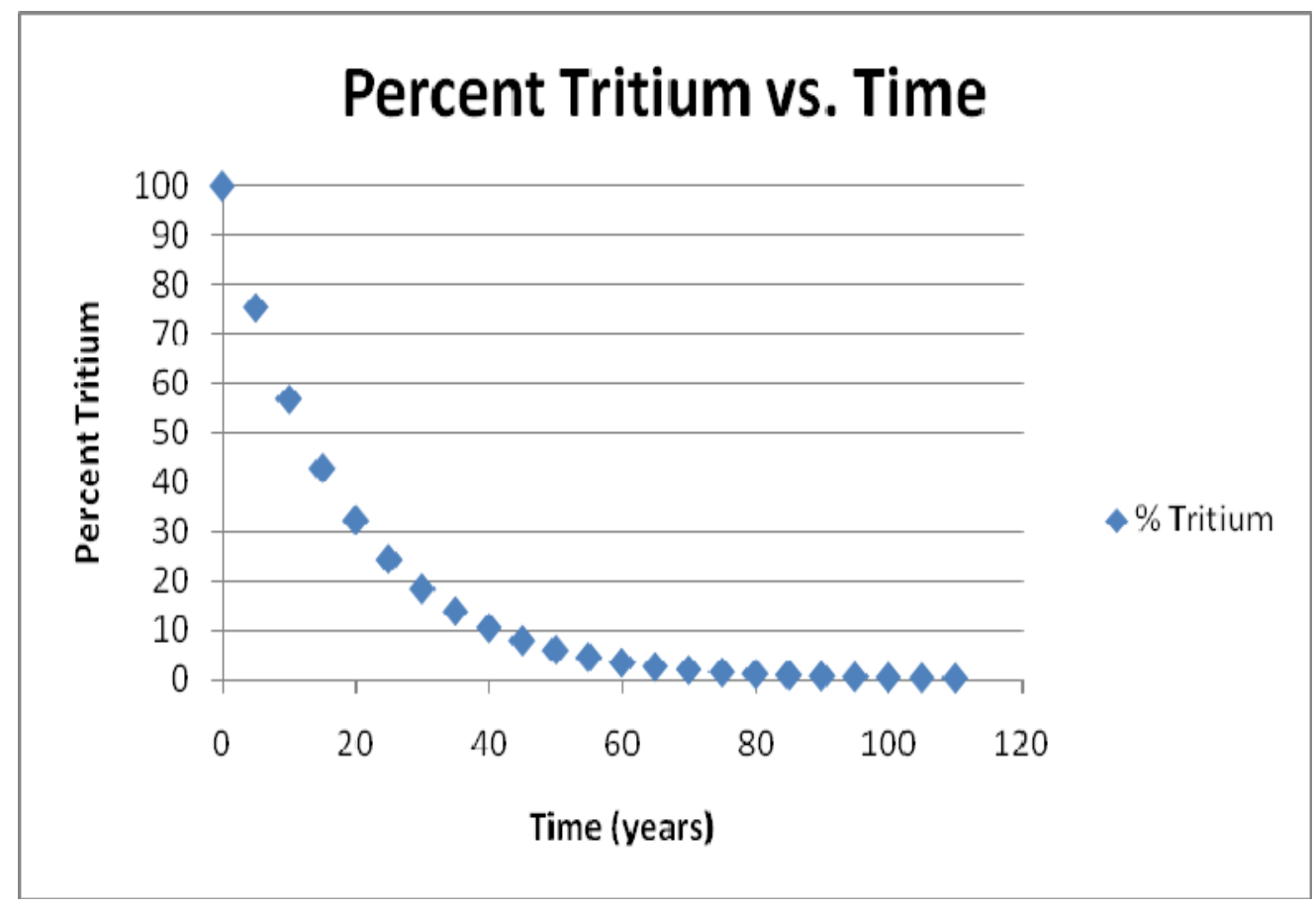

Figure 5-1. Tritium Decay Curve 
Gas samples were collected and analyzed for radionuclides following the Gasbuggy underground test (Smith and Momyer 1968). Radionuclides detected included tritium, krypton-85, iodine-131, and argon-37. The iodine and argon isotopes have short half-lives (less than 1 year) and are thus considered to be non-threatening after 40 years of decay. The radionuclides assumed to pose the largest potential risks were tritium and Krypton-85, which were estimated to have been generated in quantities of 36,000 and 350 curies, respectively (Smith and Momyer 1968). Although these two radionuclides have similar half-lives (11 years for Krypton-85 and 12 years for tritium), the sampling results confirm that tritium is the most likely indicator of contaminant migration; concentrations in test cavity gases are approximately two orders of magnitude higher than those of Krypton-85 (Smith and Momyer 1968). Since the natural gas directly affected by the detonation (tritiated methane) was flared off during the post-detonation production tests (Wethington 1969), it is assumed that all tritium encountered through present-day drilling activities would be in the form of tritiated water, either as liquid water or water vapor that is produced along with the natural gas.

\subsection{Natural Gas Production and Processing}

In order for gas contaminated with tritium (in the form of water) to be a human health concern, a complete exposure pathway must be present. Natural gas undergoes considerable processing from the time it is pumped from a single well until the time it reaches an end user (e.g., a residence). These processes significantly impact the potential exposure pathways. The processing step of most relevance with regard to the tritiated water is the "dehydrating" step, which usually involves either absorption or adsorption (NaturalGas.org 2004). Removal of water typically takes place at or near the wellhead. The final processing takes place at a larger processing plant that serves an entire region. By the time natural gas arrives at one of these regional facilities, most of the liquid has already been removed. Gas derived from an individual well is mixed with gas derived from perhaps hundreds or thousands of other wells as the gas is transported via pipeline to a large processing plant. Therefore, if gas from a handful of wells contains tritiated water, it will be highly diluted by the mixing that occurs during transport. The natural gas exiting a processing plant must satisfy established gas purity specifications, including liquid removal, before the gas can be introduced into the regional gas distribution pipeline system. The combination of liquid removal and the large dilution that takes place prior to gas arriving at an end user effectively eliminates the chance of exposure to an end user. Therefore, for conservatism, this evaluation will assume that potential exposures would occur at the wellhead where concentrations of tritium in produced water (water intermingled with natural gas) from a well would be highest.

\subsection{Risk Methodology}

Other than tritium released during the gas flaring tests conducted shortly after the Gasbuggy detonation and concluding in 1969, no tritium exceeding background levels has been detected off site over the more than 40 years of environmental monitoring in the vicinity of the Gasbuggy site. Therefore a back-calculation approach was used in an attempt to quantify potential risks associated with drilling near the site. For this assessment, it is assumed that water vapor inhaled at a well head is derived solely from contaminated water (liquid or vapor) associated with natural gas production and that inhalation is the exposure route of interest. For each scenario, it is assumed that all inhaled water vapor is contaminated. A two-step approach is used. The first step 
determines concentrations of tritium in air that would be considered protective. This is done using a risk-based and a dose-based approach for three exposure scenarios (drilling worker, maintenance worker, and a hypothetical worst-case residential scenario). Figure 5-2 shows a typical well-drilling arrangement where drilling workers would operate. Potential exposure points would be the drilling platform when lengths of drill stem are broken apart, at the mud pit, and at the reserve pit, as shown in the figure. Figure 5-3 shows a typical wellhead area that a maintenance worker would visit. Potential exposure points would be at the separator (shown on the right side of Figure 5-3) and at the holding tank, either at the vent on top of the tank or at the discharge valve, which can be seen near ground level. Next, the concentrations of tritium in produced water that would result in the target air concentrations were determined. To derive these media equivalents, the following assumptions are made:

- $\quad$ Tritiated produced water (either liquid or vapor) is the source of all water vapor available for inhalation near the wellhead.

- $\quad$ The amount of water vapor in air is limited by the absolute humidity in grams per cubic meter $\left(\mathrm{g} / \mathrm{m}^{3}\right)$ of the air.

- $\quad$ The density of liquid water is 1 gram per cubic centimeter $\left(\mathrm{g} / \mathrm{cm}^{3}\right)$.

Based on these assumptions, the relationship between air concentration and produced water concentration is given by the following equation:

Air concentration $($ picocuries per liter $[\mathrm{pCi} / \mathrm{L}])=\left[\right.$ absolute humidity $\left(\mathrm{g} / \mathrm{m}^{3}\right) \div$ water density $\left.\left(1 \mathrm{~g} / \mathrm{cm}^{3}\right)\right] \times\left[\right.$ conversion factor $\left.\left(1 \times 10^{-6} \mathrm{~m}^{3} / \mathrm{cm}^{3}\right)\right] \times$ produced water concentration $(\mathrm{pCi} / \mathrm{L})$

To determine acceptable air concentrations, it is necessary to define exposure assumptions. The Gasbuggy site is located in the Carson National Forest, New Mexico. Prior to the underground test conducted at the site, land was used for grazing and recreation. It has been recommended that land use revert back to this purpose (DOE 2009). As exposures under these expected future land uses would likely be less than those corresponding to present-day drilling activities, this analysis assumes the latter case. In this scenario, workers are likely to receive the greatest exposure to potentially contaminated air at a wellhead. The most exposure would occur during well drilling and development; lesser exposures would occur during regular operation and maintenance activities. The following estimates of worker exposure were used in the risk calculations:

- Drilling Worker Scenario: Typical duration of well drilling and development: 45 days per year (24-hour operations) for 1 year; this equates to drilling 3 wells during the year at 15 days per well (Lovato, personal communication).

- Maintenance Worker Scenario: Typical time spent by a worker at a producing well: 2 hours/month (i.e., 1 day per year) over a 30-year time frame (typical gas well lifetime)

- Inhalation rate of $30 \mathrm{~m}^{3} /$ day for both worker scenarios defined above (upper bound value for an adult; EPA 1989) 


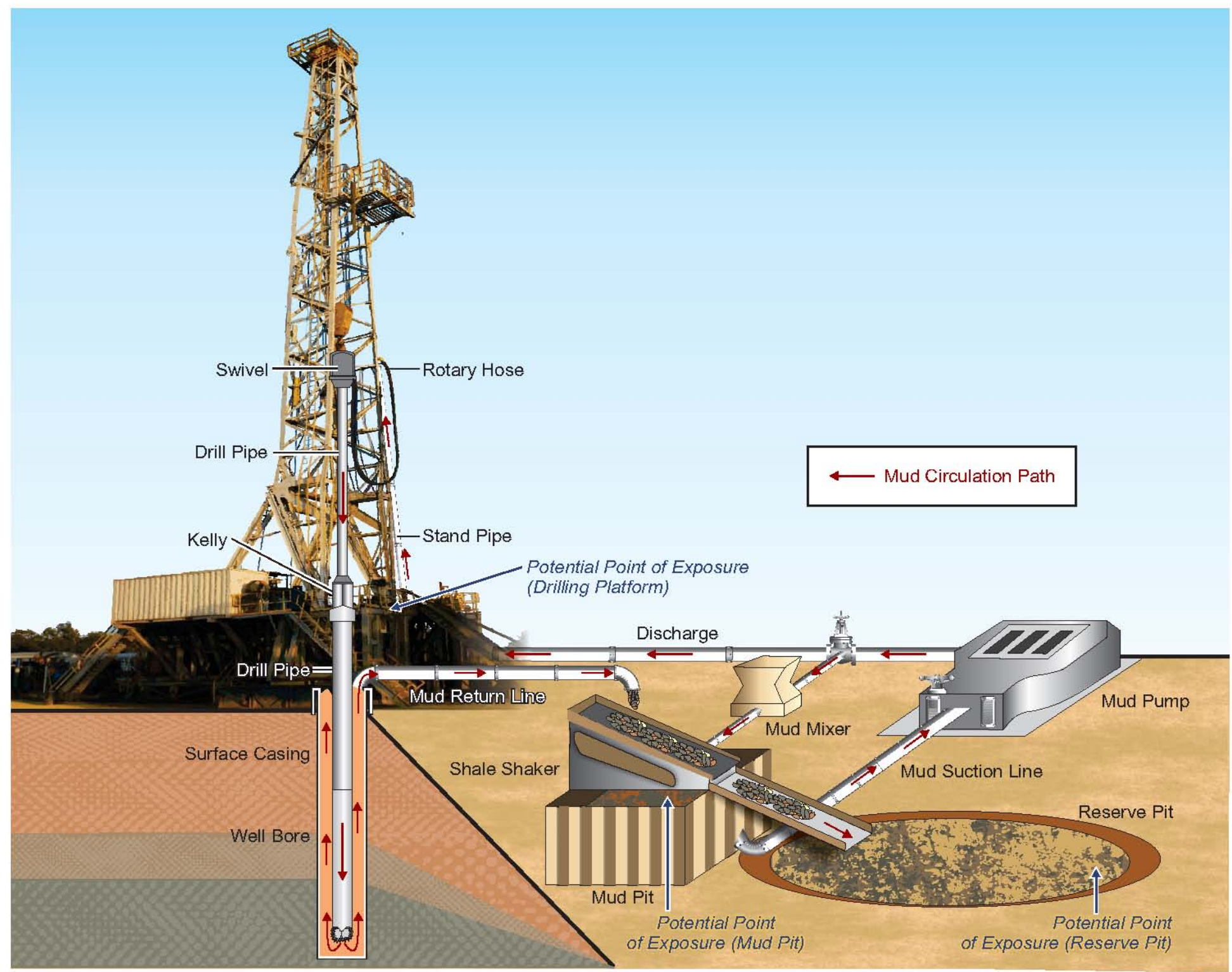

Figure 5-2. Typical Well Drilling Arrangement 


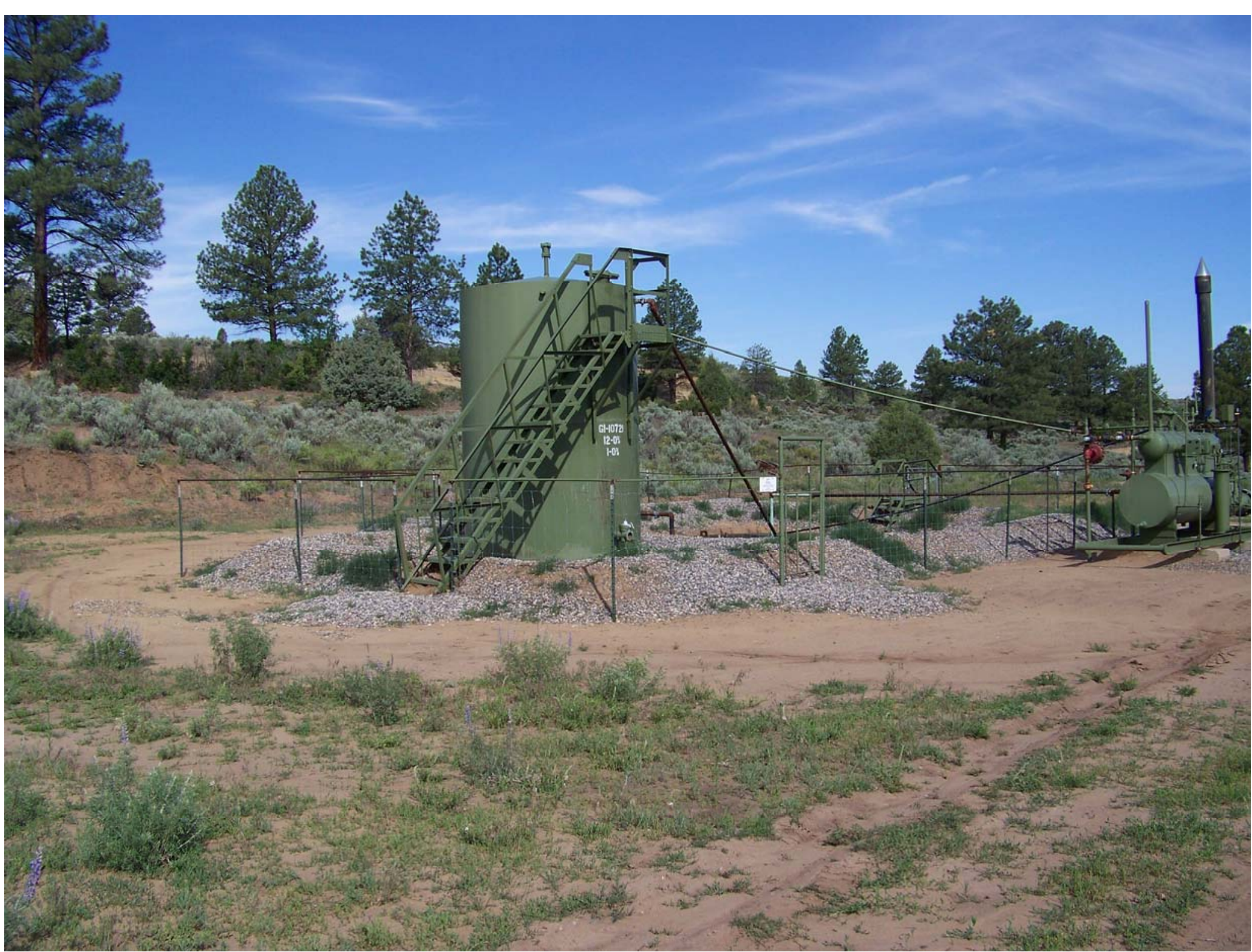

Figure 5-3. Typical Well Head Area with Separator and Separated Liquid Storage Tank 
Though highly unlikely, for purposes of comparison, calculations were also completed for a conservative hypothetical residential exposure, assuming continuous exposure over a 30-year period and an inhalation rate of $20 \mathrm{~m}^{3} /$ day (adult average; EPA 1989).

For the risk-based approach, calculated air concentrations were determined for risk levels of $10^{-6}$ and $10^{-4}$ using the tritium slope factor from Health Effects Assessment Summary Tables $\left(5.62 \times 10^{-14} \mathrm{Risk} / \mathrm{pCi}\right.$ for inhalation [EPA 2001a] $)$ and the above assumptions. Corresponding calculations are documented in Appendix A. Risk and dose-based calculated air concentrations are summarized in Table $5-1$.

For a dose-based approach, the National Emission Standards for Hazardous Air Pollutants dose limit for airborne emissions of radionuclides other than radon of 10 millirem per year (mrem/year) was used as a starting point. (This is conservative in comparison to annual dose limits established by the U.S. Nuclear Regulatory Commission— $24 \mathrm{mrem} / \mathrm{year}$ and $100 \mathrm{mrem} /$ year, depending on context and scenario.) It was assumed that exposure to tritium from produced water accounted for the entire $10 \mathrm{mrem} /$ year dose. The U.S. Environmental Protection Agency's dose conversion factor of $0.064 \mathrm{mrem} / \mathrm{microcurie}$ (IEM 2009) was used to develop a calculated air concentration (in picocuries per liter) that would result in a $10 \mathrm{mrem} /$ year dose. Computations were performed for the worker scenarios described above and for a continuous exposure scenario to develop calculated air values. These results are also summarized in Table 5-1.

Table 5-1. Calculated Air Concentrations of Tritium (pCi/L)

\begin{tabular}{||l|c|c|c||}
\hline \multicolumn{1}{|c|}{ Risk/Dose Level } & Worker/Drilling & Worker/Maintenance & Resident \\
\hline 10 mrem/year & 116 & 5,208 & 14 \\
\hline $10^{-6}$ lifetime risk & 13.2 & 19.8 & 0.0812 \\
\hline $10^{-4}$ lifetime risk & 1,320 & 1,980 & 8.12 \\
\hline
\end{tabular}

Calculated air concentrations were used in equation (1) above to determine produced water concentrations at $50{ }^{\circ} \mathrm{C}\left(122^{\circ} \mathrm{F}\right)$ over a range of absolute humidity, as documented in Appendix A. An unrealistically high temperature was used, as this results in higher amounts of water vapor held in the air at a given relative (percent) humidity, yielding a conservative estimate of exposure. At lower temperatures, less water vapor is held in the air, and exposures are lower. The reference used for humidity and temperature relationships (TIS 2009) does not indicate the altitude for the reported values; it is assumed they pertain to sea level (the reference was developed for application to marine cargo). Quantities of water held in air at higher elevations are likely lower; thus, using sea-level relationships can be considered a worst-case scenario. Table 5-2 shows concentrations of tritium in produced water equating to selected relative humidities for a representative subset of the $10 \mathrm{mrem}$ (dose-based) and $10^{-6}$ (risk-based) calculated air concentrations above. Concentrations of tritium in produced water would need to meet or exceed concentrations in Table 5-2 in order for risks to workers or residents located at a wellhead to be unacceptable. Concentrations provided in the table would be considered "safe" under the conditions listed (e.g., tritium at 1,650,000 $\mathrm{pCi} / \mathrm{L}$ would be protective for a drilling worker at the low end of the risk range at 10 percent relative humidity). 
Table 5-2. Concentrations of Tritium in Produced Water ( $p$ Ci/L) for Selected Air Concentrations and Humidities (Temperature at $50^{\circ} \mathrm{C}$ )

\begin{tabular}{||l|c|c|c|c|c||}
\hline \multicolumn{1}{|c|}{ Scenario } & $\begin{array}{c}\text { Tritium } \\
\text { Calculated Air } \\
\text { Concentration } \\
\text { (pCi/L) }\end{array}$ & $\begin{array}{c}\text { Tritium in } \\
\text { Produced Water } \\
\text { (pCi/L) at 10\% } \\
\text { Relative } \\
\text { Humidity }\end{array}$ & $\begin{array}{c}\text { Tritium in } \\
\text { Produced Water } \\
\text { (pCi/L) at 20\% } \\
\text { Relative } \\
\text { Humidity }\end{array}$ & $\begin{array}{c}\text { Tritium in } \\
\text { Produced Water } \\
\text { (pCi/L) at 50\% } \\
\text { Relative } \\
\text { Humidity }\end{array}$ & $\begin{array}{c}\text { Tritium in } \\
\text { Produced Water } \\
\text { (pCi/L) at 70\% } \\
\text { Relative } \\
\text { Humidity }\end{array}$ \\
\hline $\begin{array}{l}\text { Resident, 10 } \\
\text { risk-based }\end{array}$ & 0.0812 & 10,200 & 5,080 & 1,960 & 1,400 \\
\hline $\begin{array}{l}\text { Drilling worker, } \\
1^{-6} \text { risk based }\end{array}$ & 13.2 & $1,650,000$ & 825,000 & 318,000 & 227,000 \\
\hline $\begin{array}{l}\text { Resident, } \\
\text { dose-based }\end{array}$ & 14.3 & $1,790,000$ & 894,000 & 345,000 & 246,000 \\
\hline $\begin{array}{l}\text { Maintenance } \\
\text { Worker, 10 } \\
\text { risk-based }\end{array}$ & 19.8 & $2,480,000$ & $1,240,000$ & 477,000 & 341,000 \\
\hline $\begin{array}{l}\text { Drilling worker, } \\
\text { dose-based }\end{array}$ & 116 & $14,500,000$ & $7,230,000$ & $2,790,000$ & $1,990,000$ \\
\hline $\begin{array}{l}\text { Maintenance } \\
\text { worker, } \\
\text { dose based }\end{array}$ & 5,208 & $651,000,000$ & $326,000,000$ & $125,000,000$ & $89,600,000$ \\
\hline
\end{tabular}

\subsection{Discussion}

The primary drinking water standard for tritium is $20,000 \mathrm{pCi} / \mathrm{L}$ (EPA 2001b). EPA has not established a separate tritium standard for agricultural uses. The State of New Mexico has established a surface water tritium standard of $20,000 \mathrm{pCi} / \mathrm{L}$ for livestock use. The results in Table 5-2 indicate that if drinking water standards are met in the areas in which drilling takes place, there would be no unacceptable risk to workers. In fact, if the $20,000 \mathrm{pCi} / \mathrm{L}$ drinking water standard is met, even the hypothetical (and highly unlikely) residential scenario would result in risks within EPA's acceptable risk range of $10^{-4}$ to $10^{-6}$ (for a $10^{-4}$ risk level, tritium concentrations would be 100 times greater than the $10^{-6}$ scenario included in Table 5-2). As demonstrated above and in Appendix A, tritium concentrations in produced water would need to be extremely high (exceeding $150,000 \mathrm{pCi} / \mathrm{L}$ ), even under high humidity and temperature conditions, to result in unacceptable risks under a reasonable exposure scenario. Furthermore, the calculations assume that all water vapor inhaled for the above scenarios is derived from contaminated produced water. In reality, other noncontaminated sources of water vapor would mix with the contaminated vapor and likely result in significant dilution. This would be particularly true for a residential scenario where a residence would likely be located at some distance from the wellhead.

DOE plans to monitor for tritium in drilling fluids during drilling operations, in produced gas, and in produced water tanks during gas production in the vicinity of the Gasbuggy site. Field methods are capable of reliably detecting tritium at concentrations of approximately 4,000 $\mathrm{pCi} / \mathrm{L}$ during drilling operations. These field-detectable concentrations would not be of concern from a human health perspective, but are more than adequate to make the determination that drilling operations can safely continue or that drilling should pause, and further evaluation is necessary before continuing drilling operations. The large margin between reliable tritium field detection concentrations and tritium concentrations that cause human health concerns will ensure that drilling activities can be conducted safely and controlled if necessary to protect workers. 
This page intentionally left blank 


\subsection{References}

AEC (U.S. Atomic Energy Commission), 1971. Project Gasbuggy Manager's Report, PNE-G-79, NVO-37. Las Vegas, NV.

Benjamin, Sally, and David Belluck, 1994. State Groundwater Regulation, Guide to Laws, Standards, and Risk Assessment, Bureau of National Affairs, Inc., Washington, DC.

Brown, B., 1910. The Cretaceous Ojo Alamo Beds of New Mexico with Description of the New Dinosaur Genus Kritosaurus, Bulletin American Museum of Natural History, Vol. XXVIII, 1910.

DRI (Desert Research Institute), 2003. Investigations in Well EPNG 10-36 at the Gasbuggy Nuclear Test Site, Rio Arriba County, New Mexico, prepared by Brad Lyles, Jenny Chapman, and David Gillespie, Division of Hydrologic Sciences, Desert Research Institute, University and Community College System of Nevada; DOE/NV/13609-31, September.

DRI (Desert Research Institute), 2009. Letter Report, Conceptual Model Uncertainty and Data Adequacy for Gasbuggy Underground Nuclear Test Site Contaminant Transport Calculations, prepared by Jenny B. Chapman, Desert Research Institute, Nevada System of Higher Education; LMS/GSB/S05024, February.

DOE (U.S. Department of Energy), 2002. Site Characterization Work Plan for Gasbuggy, New Mexico, Nevada Operations Office report DOE/NV-690-REV.1.

DOE (U.S. Department of Energy), 2008. Natural Gas Drilling Near the Project Rulison Area: A Human Health Risk Perspective; Appendix A, "Path Forward Report for Project Rulison,” Draft, Argonne National Laboratory, December.

DOE (U.S. Department of Energy), 2009. Gasbuggy, New Mexico, Site Fact Sheet, Office of Legacy Management, Grand Junction, Colorado, April, http://www.lm.doe.gov/gasbuggy/Sites.aspx, accessed September 10, 2009.

EPA (U.S. Environmental Protection Agency), 2001a. Radionuclide Carcinogenicity Slope Factors: Health Effects Assessment Summary Tables (HEAST), April 16, 2001, update, http://www.epa.gov/rpdweb00/heast/, accessed September 10, 2009.

EPA (U.S. Environmental Protection Agency), 2001b. Use of Uranium Drinking Water Standards under 40 CFR 141 and 40 CFR 192 as Remediation Goals for Groundwater at CERCLA sites, OSWER Directive 9283.1-14, November 6.

EPA (U.S. Environmental Protection Agency), 1989. Exposure Factors Handbook, Office of Health and Environmental Assessment, EPA/600/8-89/043.

Holzer, F., 1970. “Gasbuggy in Perspective,” in Proceedings of the American Nuclear Society Symposium of Engineering with Nuclear Explosives: 662-697, CONF-700101, Vol. 1, American Nuclear Society, Washington, DC. 
IEM (Integrated Environmental Management, Inc.), 2009. Dose Conversion Factors, http://www.iem-inc.com/tooldcf.html accessed September 10, 2009.

Lovato, personal communication. Personal communication with Jim Lovato, Petroleum Engineer, U.S. Bureau of Land Management, Farmington, NM, field office, December 2010.

LRL (Lawrence Radiation Laboratory), 1968a. Gasbuggy Postshot Investigations in GB-ER, UCRL-50425, prepared by J.A. Korver and D.E. Rawson, Livermore, CA.

LRL (Lawrence Radiation Laboratory), 1968b. Gasbuggy Preliminary Postshot Summary Report, UCRL-50386, prepared by F. Holzer, Livermore, CA.

Mercer, J.W., 1968. Inventory of Wells and Springs within a 10-mile radius of Project Gasbuggy, Rio Arriba County, New Mexico, Open-file Report, U.S. Geological Survey.

Mercer, J.W., 1970. "Hydrology of Project Gasbuggy Site, Rio Arriba County, New Mexico," U.S. Geological Survey Report Series, Nuclear Explosions_Peaceful Applications, PNE-1013, TID-4500.

NaturalGas.org, 2004. Overview of Natural Gas, website developed and maintained by the Natural Gas Supply Association, http://www.naturalgas.org/overview/overview.asp, accessed September 10, 2009.

New Mexico, 2003. San Juan Basin Regional Water Plan San Juan Hydrologic Unit, available at http://www.seo.state.nm.us/isc_regional_plans2.html, accessed July 2008.

Power, D.V., and C.R. Bowman, 1970. “An Evaluation of Water Production from the Gasbuggy Reentry Well,” in Proceedings, American Nuclear Society Symposium on Engineering with Nuclear Explosives, PNE-G-58, Conf. 700101-11, American Nuclear Society, La Grange Park, IL.

Smith, C.F. and Momyer, F.F., 1968. Gas Quality Investigation Programs Status Report for Project Gasbuggy, Lawrence Radiation Laboratory, PNE-G-10, UCRL-71314, Rev. 1, November.

Sokol, D., 1970. Ground Water Safety Evaluation-Project Gasbuggy, PNE-1009, prepared by Teledyne Isotopes, U.S. Atomic Energy Commission, Nevada Operations Office.

Stone, W.J., F.P. Lyford, P. F., Frenzel, N.H. Mizell, and E.T. Padgett, 1983. Hydrogeology and Water Resources of San Juan Basin, New Mexico: Socorro, New Mexico, Bureau of Mines and Mineral Resources Hydrologic Report 6.

Stosur, J.J., 1977. "Current Status of Projects Gasbuggy, Rulison, and Rio Blanco, and an Appraisal of Nuclear-Explosive Fracturing Potential in the Near Future,” in The Future Supply of Nature-Made Petroleum and Gas, Technical Reports: 697-721, R.F. Meyer, ed., Pergamon Press, New York, NY. 
TIS (Transport Information Service), 2009. Climate/Humidity Table, http://www.tisgdv.de/tis_e/misc/klima.htm, accessed September 10, 2009.

Wethington, John A., Jr. Possible Techniques for Decontamination of Natural Gas from

Gas Wells Stimulated by a Nuclear Explosion, Lawrence Radiation Laboratory, UCRL-72087, October. 
This page intentionally left blank 
Appendix A

Air Risks 
This page intentionally left blank 


\section{Worker Risks}

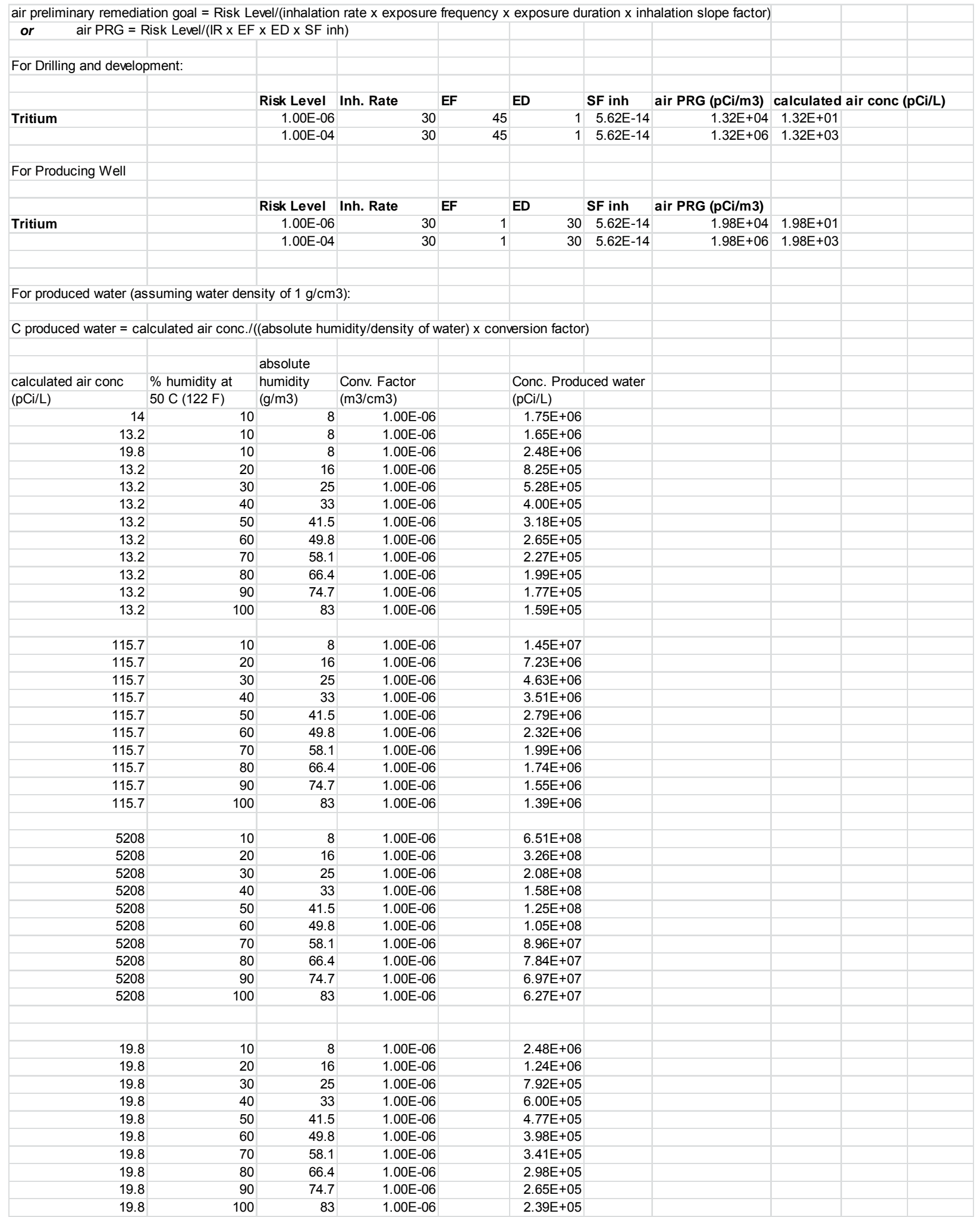


Residential Risks

\begin{tabular}{|c|c|c|c|c|c|c|c|c|c|}
\hline \multicolumn{10}{|l|}{ Residential } \\
\hline \multicolumn{10}{|c|}{ air PRG $=$ Risk Level/(inhalation rate $\mathrm{x}$ exposure frequency $\mathrm{x}$ exposure duration $\mathrm{x}$ inhalation slope factor) } \\
\hline \multirow[t]{3}{*}{ or air $\mathrm{PRG}=$ Risk } & $\mathrm{k}$ Level/(IR $\times \mathrm{EF} \times \mathrm{E}$ & ED $\times$ SF inh) & & & & \multirow{4}{*}{ SF inh } & \multirow[b]{3}{*}{ air PRG (pCi/m3) } & & \\
\hline & & & & & & & & & \\
\hline & & Risk Level & Inh. Rate & EF & ED & & & \multicolumn{2}{|c|}{ calculated air conc (pCi/L) } \\
\hline \multirow[t]{4}{*}{ Tritium } & & 1.00E-06 & (20) & 365 & 30 & & $8.12 \mathrm{E}+01$ & 8.12E-02 & \\
\hline & & 1.00E-04 & 20 & 365 & 30 & $5.62 \mathrm{E}-14$ & $8.12 \mathrm{E}+03$ & $8.12 \mathrm{E}+00$ & \\
\hline & & & & & & & & & \\
\hline & & & & & & & & & \\
\hline \multicolumn{10}{|c|}{ For produced water (assuming water density of $1 \mathrm{~g} / \mathrm{cm} 3$ ) } \\
\hline & & & & & & & & & \\
\hline \multicolumn{10}{|c|}{$\mathrm{C}$ produced water $=$ calculated air conc./((absolute humidity/density of water $) \times$ conversion factor $)$} \\
\hline \multirow{4}{*}{$\begin{array}{l}\text { calculated air conc } \\
(\mathrm{pCi} / \mathrm{L})\end{array}$} & & & & & & & & & \\
\hline & & absolute & & & & & & & \\
\hline & $\%$ humidity at & humidity & Conv. Factor & & \multicolumn{2}{|c|}{ Conc. Produced water } & & & \\
\hline & $50 \mathrm{C}(122 \mathrm{~F})$ & $(g / m 3)$ & $(\mathrm{m} 3 / \mathrm{cm} 3)$ & & $(\mathrm{pCi} / \mathrm{L})$ & & & & \\
\hline & & & & & & & & & \\
\hline 8.12 & 10 & 8 & $1.00 \mathrm{E}-06$ & & $1.02 \mathrm{E}+06$ & & & & \\
\hline 8.12 & 20 & 16 & 1.00E-06 & & $5.08 \mathrm{E}+05$ & & & & \\
\hline 8.12 & 30 & 25 & $1.00 \mathrm{E}-06$ & & $3.25 \mathrm{E}+05$ & & & & \\
\hline 8.12 & 40 & 33 & $1.00 \mathrm{E}-06$ & & $2.46 \mathrm{E}+05$ & & & & \\
\hline 8.12 & 50 & 41.5 & 1.00E-06 & & $1.96 \mathrm{E}+05$ & & & & \\
\hline 8.12 & 60 & 49.8 & 1.00E-06 & & $1.63 E+05$ & & & & \\
\hline 8.12 & 70 & 58.1 & $1.00 \mathrm{E}-06$ & & $1.40 \mathrm{E}+05$ & & & & \\
\hline 8.12 & 80 & 66.4 & 1.00E-06 & & $1.22 \mathrm{E}+05$ & & & & \\
\hline 8.12 & 90 & 74.7 & $1.00 \mathrm{E}-06$ & & $1.09 \mathrm{E}+05$ & & & & \\
\hline 8.12 & 100 & 83 & 1.00E-06 & & $9.78 \mathrm{E}+04$ & & & & \\
\hline & & & & & & & & & \\
\hline 8.12E-02 & 10 & 8 & 1.00E-06 & & $1.02 \mathrm{E}+04$ & & & & \\
\hline 8.12E-02 & 20 & 16 & $1.00 \mathrm{E}-06$ & & $5.08 \mathrm{E}+03$ & & & & \\
\hline $8.12 \mathrm{E}-02$ & 30 & 25 & $1.00 \mathrm{E}-06$ & & $3.25 E+03$ & & & & \\
\hline $8.12 \mathrm{E}-02$ & 40 & 33 & $1.00 \mathrm{E}-06$ & & $2.46 \mathrm{E}+03$ & & & & \\
\hline 8.12E-02 & 50 & 41.5 & 1.00E-06 & & $1.96 \mathrm{E}+03$ & & & & \\
\hline 8.12E-02 & 60 & 49.8 & 1.00E-06 & & $1.63 E+03$ & & & & \\
\hline 8.12E-02 & 70 & 58.1 & $1.00 \mathrm{E}-06$ & & $1.40 \mathrm{E}+03$ & & & & \\
\hline $8.12 \mathrm{E}-02$ & 80 & 66.4 & 1.00E-06 & & $1.22 \mathrm{E}+03$ & & & & \\
\hline 8.12E-02 & 90 & 74.7 & 1.00E-06 & & $1.09 \mathrm{E}+03$ & & & & \\
\hline 8.12E-02 & 100 & 83 & 1.00E-06 & & $9.78 \mathrm{E}+02$ & & & & \\
\hline & & & & & & & & & \\
\hline $1.43 \mathrm{E}+01$ & 10 & 8 & $1.00 \mathrm{E}-06$ & & $1.79 E+06$ & & & & \\
\hline $1.43 \mathrm{E}+01$ & 20 & 16 & 1.00E-06 & & $8.94 \mathrm{E}+05$ & & & & \\
\hline $1.43 \mathrm{E}+01$ & 30 & 25 & 1.00E-06 & & $5.72 \mathrm{E}+05$ & & & & \\
\hline $1.43 E+01$ & 40 & 33 & 1.00E-06 & & $4.33 E+05$ & & & & \\
\hline $1.43 E+01$ & 50 & 41.5 & 1.00E-06 & & $3.45 \mathrm{E}+05$ & & & & \\
\hline $1.43 E+01$ & 60 & 49.8 & 1.00E-06 & & $2.87 \mathrm{E}+05$ & & & & \\
\hline $1.43 E+01$ & 70 & 58.1 & 1.00E-06 & & $2.46 \mathrm{E}+05$ & & & & \\
\hline $1.43 \mathrm{E}+01$ & 80 & 66.4 & $1.00 \mathrm{E}-06$ & & $2.15 \mathrm{E}+05$ & & & & \\
\hline $1.43 E+01$ & 90 & 74.7 & $1.00 \mathrm{E}-06$ & & $1.91 \mathrm{E}+05$ & & & & \\
\hline $1.43 \mathrm{E}+01$ & 100 & 83 & $1.00 \mathrm{E}-06$ & & $1.72 \mathrm{E}+05$ & & & & \\
\hline
\end{tabular}




\section{Dose Calculations}

Calculated air conc $=$ Dose limit/(Dose Conversion Factor $\mathrm{x}$ Inhalation rate $\mathrm{x}$ exposure frequency $\mathrm{x}$ conversion factor) or Calculated air concentration $=$ Dose limit $\times$ DCF $\times I R \times E F \times$ Conv. Factor

\begin{tabular}{|c|c|c|c|c|c|}
\hline Dose limit & DCF & IR & EF & Conv. Factor & calculated air conc \\
\hline (mrem/yr) & (mrem/pCi) & (m/day) & (days/yr) & (L/m3) & (pCi/L) \\
\hline 10 & $6.40 \mathrm{E}-08$ & $3.00 \mathrm{E}+01$ & 45 & 1000 & 115.7 \\
\hline 10 & $6.40 \mathrm{E}-08$ & $2.00 \mathrm{E}+01$ & 365 & 1000 & 21.4 \\
\hline 10 & 6.40E-08 & $3.00 \mathrm{E}+01$ & 1 & 1000 & 5208.3 \\
\hline
\end{tabular}

Dose limit is NESHAP limit for airborne emissions of radionuclides other than radon. 
This page intentionally left blank 


\title{
Library Distribution List
}

\author{
$\underline{\text { Copies }}$
}

U.S. Department of Energy

1 (Uncontrolled)

National Nuclear Security Administration

Nevada Site Office

Technical Library

P.O. Box 98518, M/S 505

Las Vegas, NV 89193-8518

702-295-3521

U.S. Department of Energy

1 (Uncontrolled, electronic copy)

Office of Scientific and Technical Information

P.O. Box 62

Oak Ridge, TN 37831-0062

865-576-8401

Southern Nevada Public Reading Facility

c/o Nuclear Testing Archive

2 (Uncontrolled, electronic copies)

P.O. Box 98521, M/S 400

Las Vegas, NV 89193-8521 
This page intentionally left blank 